\title{
Perempuan Nelayan
}

\section{Catatan Jurnal Perempuan}

Perempuan Nelayan

\section{Artikel}

Eksistensi dan Kekuatan Perempuan Nelayan di Desa Morodemak dan Purworejo: Melawan Kekerasan, Birokrasi \& Tafsir Agama yang Bias

Andi Misbahul Pratiwi \& Abby Gina

Perjuangan Rekognisi Identitas Hukum Perempuan Nelayan Ujung Pangkah, Gresik: Analisis Feminis terhadap Kebijakan Kartu dan Asuransi Nelayan

Naufaludin Ismail

Perempuan dalam Sektor Perikanan Berbasis Gender: Peran, Isu dan Tantangan di Kamboja, Indonesia, Vietnam dan Filipina

Ma. Linnea Villarosa-Tanchuling

Reklamasi Teluk Jakarta, Pemiskinan dan Marginalisasi Perempuan Nelayan: Studi Kasus di Kampung Akuarium dan Kamal Muara, Penjaringan

Endah Kusuma Wardhani

Peran Produksi, Reproduksi dan Sosial Kemasyarakatan Perempuan Pengolah Kerang Hijau di Muara Angke, Jakarta Utara

Yekti Wahyuni

Kapabilitas Manusia untuk Pembangunan yang Berkeadilan: Studi Kasus Perempuan Petambak Udang di

Dipasena, Lampung

Gadis Arivia \& Abby Gina

\section{Wawancara}

Dedi Adhuri: Marginalisasi Perempuan Nelayan adalah Produk Kultur dan Kebijakan yang Diskriminatif Abby Gina

\section{Kata Makna}

Nur Iman Subono

\section{Profil}

Masnuah, Pejuang Hak-Hak Perempuan Nelayan

Andy Misbahul Pratiwi

\section{Resensi Buku}

Ketika Pembangunan Mengabaikan Hak-Hak Perempuan dan Anak Naufaludin Ismail

Diterbitkan oleh:

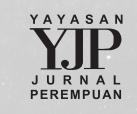


ISSN 1410-153X

\section{PENDIRI}

Dr. Gadis Arivia

Prof. Dr. Toeti Heraty Noerhadi-Roosseno

Ratna Syafrida Dhanny

Asikin Arif (Alm.)

\section{DEWAN PEMBINA}

Melli Darsa, S.H., LL.M.

Mari Elka Pangestu, Ph.D.

Svida Alisjahbana

\section{PEMIMPIN REDAKSI}

Anita Dhewy

\section{DEWAN REDAKSI}

Atnike Nova Sigiro, M.Sc. (Human Rights Diplomacy, Universitas Paramadina)

Prof. Dr. Sulistyowati Irianto (Antropologi Hukum Feminisme, Universitas Indonesia)

Prof. Sylvia Tiwon (Antropologi Gender, University California at Berkeley)

Prof. Saskia Wieringa (Sejarah Perempuan \& Queer, Universitaet van Amsterdam)

Prof. Dr. Musdah Mulia (Pemikiran Politik Islam \& Gender, UIN Syarif Hidayatullah)

Dr. Nur Iman Subono (Politik \& Gender, FISIPOL Universitas Indonesia)

Mariana Amiruddin, M.Hum (Komisi Nasional Anti Kekerasan terhadap Perempuan)

Yacinta Kurniasih, M.A. (Sastra dan Perempuan, Faculty of Arts, Monash University)

Soe Tjen Marching, Ph.D (Sejarah dan Politik Perempuan, SOAS University of London)

\section{MITRA BESTARI}

Prof. Mayling Oey-Gardiner (Demografi \& Gender, Universitas Indonesia)

David Hulse, PhD (Politik \& Gender, Ford Foundation)

Dr. Pinky Saptandari (Politik \& Gender, Universitas Airlangga)

Dr. Kristi Poerwandari (Psikologi \& Gender, Universitas Indonesia)

Dr. Ida Ruwaida Noor (Sosiologi Gender, Universitas Indonesia)

Katharine McGregor, PhD. (Sejarah Perempuan, University of Melbourne)

Prof. Jeffrey Winters (Politik \& Gender, Northwestern University)

Ro'fah, PhD. (Agama \& Gender, UIN Sunan Kalijaga)

Tracy Wright Webster, PhD. (Gender \& Cultural Studies University of Western Australia)

Prof. Kim Eun Shil (Antropologi \& Gender, Korean Ewha Womens University)

Prof. Merlyna Lim (Media, Teknologi \& Gender, Carleton University)

Prof. Claudia Derichs (Politik \& Gender, Universitaet Marburg)
Sari Andajani, PhD. (Antropologi Medis, Kesehatan Masyarakat \& Gender, Auckland University of Technology)

Dr. Wening Udasmoro (Budaya, Bahasa \& Gender, Universitas Gajah Mada)

Prof. Ayami Nakatani (Antropologi \& Gender, Okayama University)

Antarini Pratiwi Arna (Hukum \& Gender, Gender Justice Program Director-Oxfam in Indonesia)

Prof. Maria Lichtmann (Teologi Kristen dan Feminisme, Appalachian State University, USA)

Assoc. Prof. Muhamad Ali (Agama \& Gender, University California, Riverside)

Assoc. Prof. Mun'im Sirry (Teologi Islam \& Gender, University of Notre Dame)

Assoc. Prof. Paul Bijl (Sejarah, Budaya \& Gender, Universiteit van Amsterdam)

Assoc. Prof. Patrick Ziegenhain (Politik \& Gender, Goethe University Frankfurt)

Assoc. Prof. Alexander Horstmann (Studi Asia \& Gender, University of Copenhagen)

\section{REDAKSI PELAKSANA}

Andi Misbahul Pratiwi

\section{REDAKSI}

Abby Gina Boangmanalu

Naufaludin Ismail

SEKRETARIAT DAN SAHABAT JURNAL PEREMPUAN

Himah Sholihah

Gery Andri Wibowo

Hasan Ramadhan

\section{DESAIN \& TATA LETAK \\ Elisabet Dwi}

\section{ALAMAT REDAKSI :}

Jl. Karang Pola Dalam II No. 9A, Jati Padang

Pasar Minggu, Jakarta Selatan 12540

Telp./Fax (021) 22701689

E-mail: yjp@jurnalperempuan.com

redaksi@jurnalperempuan.com

WEBSITE:

indonesianfeministjournal.org

Cetakan Pertama, November 2017

\section{FORDFOUNDATION}

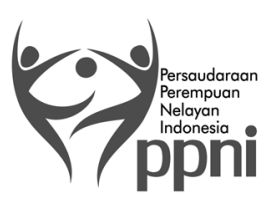




\section{Perempuan 95 Perempuan Nelayan Fisherwomen}

\section{Daftar Isi}

\section{Catatan Jurnal Perempuan}

Perempuan Nelayan / Fisherwomen

\section{Artikel / Articles}

- Eksistensi dan Kekuatan Perempuan Nelayan di Desa Morodemak dan Purworejo: Melawan Kekerasan, Birokrasi \& Tafsir Agama yang Bias / The Existence and Power of Fisherwomen in Morodemak and Purworejo Villages: Against Violence, Bureaucracy \& Biased of Religious Interpretation

Andi Misbahul Pratiwi \& Abby Gina

- Perjuangan Rekognisi Identitas Hukum Perempuan Nelayan Ujung Pangkah, Gresik: Analisis Feminis terhadap Kebijakan Kartu dan Asuransi Nelayan / Struggle of Legal Identity Recognition of Fisherwomen in Ujung Pangkah, Gresik: Feminist Analysis toward Regulation on Fishermen Card and Insurance. Naufaludin Ismail

- Perempuan dalam Sektor Perikanan Berbasis Gender: Peran, Isu dan Tantangan di Kamboja, Indonesia, Vietnam dan Filipina / Women in Gendered Fisheries: Roles, Issues and Challenges in Cambodia, Indonesia, Vietnam and Philippines.

Ma. Linnea Villarosa-Tanchuling

- Reklamasi Teluk Jakarta, Pemiskinan dan Marginalisasi Perempuan Nelayan: Studi Kasus di Kampung Akuarium dan Kamal Muara, Penjaringan / Reclamation of Jakarta Bay, Impoverishment and Marginalization of Fisherwomen: Case Study at Akuarium and Kamal Muara Village, Penjaringan.

Endah Kusuma Wardhani

- Peran Produksi, Reproduksi dan Sosial Kemasyarakatan Perempuan Pengolah Kerang Hijau di Muara Angke, Jakarta Utara / Productive, Reproductive and Community Roles of Women Who Process Green Shells in Muara Angke, North Jakarta. Yekti Wahyuni

- Kapabilitas Manusia untuk Pembangunan yang Berkeadilan: Studi Kasus Perempuan Petambak Udang di Dipasena, Lampung / Human Capabilities for Fair Development: Case Study of Women Prawn Farmers in Dipasena, Lampung. 359-368

Gadis Arivia \& Abby Gina

\section{Wawancara / Interview}

Dedi Adhuri: Marginalisasi Perempuan Nelayan adalah Produk Kultur dan Kebijakan yang Diskriminatif / Dedi Adhuri: Marginalization of Fisherwomen is Cultural Product and Discriminatory Policy.

Abby Gina

\section{Kata Makna / Words and Meaning}

Nur Iman Subono

Profil / Profile

Masnuah, Pejuang Hak-Hak Perempuan Nelayan / Masnuah, Fisherwomen Rights Defender. 377-383

Andy Misbahul Pratiwi

Resensi Buku / Book Review

Ketika Pembangunan Mengabaikan Hak-Hak Perempuan dan Anak / When Development Disregards Women's and Children's Rights $385-388$ Naufaludin Ismail 


\section{Perempuan Nelayan \\ Fisherwomen}

"Poros Maritim" dicanangkan oleh Presiden Joko Widodo sebagai program utama dalam pemerintahannya. la berjanji saat kampanye untuk menempatkan nelayan sebagai aktor utama. Namun setelah 2,5 tahun masa pemerintahannya, niat presiden belum terwujud dan hal ini membuat sebagian besar nelayan kecewa. Pada tanggal 6 April 2017, di hari nelayan, mereka berdemonstrasi di depan kantor Kementerian Kelautan dan Perikanan (KKP) dan Istana Merdeka Jakarta menagih janji Presiden Joko Widodo (CNN Indonesia 2017). Masalah perikanan memang masalah penting sebab sedikitnya 200 juta orang bekerja sebagai nelayan tradisional terutama di negaranegara dunia berkembang. Peran mereka sangat besar sebab 70 persen kontribusi produksi perikanan dunia berasal dari mereka. Di tahun 2010 diperkirakan manusia mengonsumsi 128 juta ton ikan dan di dalam satu dekade terakhir ikan dikonsumsi 4,3 miliar orang. Di tahun 2021 diperkirakan 172 juta orang akan mengonsumsi ikan dan industri ini akan menjadi industri yang paling cepat berkembang (FAO 2012).

Undang-Undang Nomor 7 tahun 2016 tentang Perlindungan dan Pemberdayaan Nelayan, Pembudi Daya Ikan dan Petambak Garam sebenarnya sangat positif karena dimaksudkan untuk melindungi nelayan kecil. Namun implementasi kebijakan tersebut justru menyengsarakan nelayan kecil terutama perempuan nelayan. Sayangnya diskursus tentang perempuan nelayan masih sangat minim dan tidak diperhitungkan sebab definisi nelayan cenderung diartikan sebagai yang menangkap ikan sedangkan perempuan berperan sebagian besar sebagai pembersih ikan untuk dikonsumsi di rumah atau menjualnya di pasar-pasar. Mereka kadang tidak menerima upah di dalam bisnis rumah tangga. Bila pun mereka menangkap ikan di laut mereka dianggap hanya menemani suami. Definisi nelayan inilah yang membuat perempuan tidak diperhitungkan di sektor perikanan. Kontribusi perempuan nelayan dianggap tidak ada dan ini berdampak buruk terhadap perempuan nelayan karena tidak bisa mendapatkan akses kredit, teknologi pengolahan, fasilitas gudang pendinginan dan pelatihan-pelatihan yang diselenggarakan oleh pemerintah (Kabar Bahari edisi 18 November-Desember 2015).

Panduan Sukarela untuk Menjamin Perikanan Skala Kecil (Voluntary Guidelines for Securing Sustainable Small-Scale Fisheries) dalam konteks keamanan pangan dan penghapusan kemiskinan menyebutkan secara tegas kewajiban negara untuk memperlakukan perempuan nelayan termasuk pembudidaya dan petambak garam secara istimewa dan hakhaknya dijamin. Jaminan tersebut antara lain mendapatkan perumahan yang layak, sanitasi dasar yang aman dan higienis, tabungan investasi dan kredit, bebas dari pelecehan seksual dan kekerasan, pengembangan teknologi, dan sebagainya, dengan merujuk kepada CEDAW. Bila perempuan nelayan tidak dijamin hak-haknya dan tidak didukung keberadaannya maka dapat diperkirakan bahwa kelompok miskin terbesar tentu datang dari golongan ini. Itu sebabnya, pemerintah harus memberikan perhatian khusus pada perempuan nelayan dan mengubah definisi nelayan yang sangat maskulin. Bila hal ini tidak dilakukan maka pencapaian SDGs dalam mempromosikan kesetaraan gender dan pemberdayaan perempuan akan gagal terutama komponen esensial seperti pemberantasan kemiskinan, ketahanan pangan, kesinambungan pembangunan dari perikanan dan sumber daya laut.

Oleh sebab itu, analisis gender dalam soal perikanan dan sumber daya laut menjadi penting agar produktivitas dan keadilan terhadap perempuan terjamin. Hal yang perlu dilakukan adalah melakukan advokasi mengenai kesetaraan gender, membentuk"champions" (yang dapat memajukan hakhak perempuan nelayan), kerja sama dengan peneliti dan para ahli kebijakan. Koalisi besar ini dibutuhkan antara LSM, pemerintah, peneliti dan akademisi. Banyak pengalaman menunjukkan bahwa lensa gender dibutuhkan dalam memformulasi kebijakan perikanan yang menitikberatkan pada hak-hak perempuan. Selama ini perspektif gender dalam isu perikanan sangat lemah karena hanya fokus pada produksi ikan yang dikuasai oleh laki-laki. Selain itu, peranan perempuan nelayan harus masuk ke dalam semua instrumen internasional maupun nasional (Alami \& Raharjo 2017).

Menyadari pentingnya peran dan kontribusi perempuan nelayan bagi perekonomian keluarga dan masyarakat, Jurnal Perempuan mengadakan riset di tiga wilayah yakni Dipasena, Demak dan Gresik untuk mengungkap tantangan, strategi dan upaya yang dilakukan perempuan nelayan guna mendapat pengakuan, perlindungan dan pemberdayaan. Langkah kami mendokumentasikan pengalaman dan suara perempuan nelayan dapat terwujud berkat kerja sama dengan Kiara, PPNI, P3UWdan Puspita Bahari. Hasil risetselain kamidokumentasikan dalam JP edisi ini juga kami narasikan dalam bentuk film dokumenter. Edisi ini diharapkan dapat mendorong adanya pengakuan, perlindungan dan pemberdayaan perempuan nelayan dengan membuka akses bagi perempuan nelayan untuk mendapatkan kartu nelayan. Begitu juga dengan keberadaan film dokumenter, diharapkan dapat bermanfaat bagi proses advokasi perempuan nelayan di Indonesia.

(Anita Dhewy) 


\section{Jurnal Perempuan, Vol. 22 No. 4, November 2017 \\ Lembar Abstrak/Abstracts Sheet}

\author{
Andi Misbahul Pratiwi \& Abby Gina \\ (Jurnal Perempuan, Jakarta, Indonesia)
}

\section{Eksistensi dan Kekuatan Perempuan Nelayan di Desa Morodemak dan Purworejo: Melawan Kekerasan, Birokrasi \& Tafsir Agama yang Bias}

\section{The Existence and Power of Fisherwomen in Morodemak and Purworejo Villages: Against Violence, Bureaucracy \& Biased of Religious Interpretation}

\section{DDC: 305}

Jurnal Perempuan, Vol. 22 No. 4, November 2017, hal. 295-309, 3 tabel, 10 daftar pustaka

This research was conducted in Morodemak and Purworejo Village, Demak District, Central Java Province, Indonesia, by focusing on the problem faced by fisherwomen - who go to sea as well as who process the catches - and the activism of Puspita Bahari (fisherwomen organization in Demak). This research seeks to show that women have contributed to the economic progress of coastal communities. This research became a personal research because the researchers have the opportunity to observe the activity of fisherwomen who go to sea and also in the research process, the researchers participated in the advocacy process to get recognition as fisherwomen. By using Naila Kabeer gender analysis, this research found that the complexity of the problems faced by fisherwomen are layers ranging from family, community, market until state levels. The issues of the division of labor, the biased bureaucracy and domestic violence are the three main topics that studied in this paper. Recognition of the identity of fisherwomen becomes an urgency and first step that should be realized in order to improve fisherwomen condition.

Keywords: exisistence of fisherwomen, fisherwomen, morodemak, purworejo, tambak polo, domestic violence.

Penelitian ini dilakukan di Desa Morodemak dan Desa Purworejo dengan memfokuskan pada persoalan yang dihadapi oleh perempuan nelayan-yang melaut maupun yang mengolah hasil tangkapandan aktivisme Puspita Bahari. Penelitian ini berupaya menunjukkan bahwa perempuan memiliki kontribusi pada kemajuan ekonomi masyarakat pesisir. Penelitian ini menjadi penelitian yang personal karena penulis berkesempatan melakukan observasi langsung terhadap aktivitas perempuan nelayan yang melaut dan juga karena dalam perjalanannya peneliti ikut dalam perjuangan perempuan nelayan untuk mendapatkan pengakuan sebagai nelayan. Dengan menggunakan analisis gender Naila Kabeer penelitian ini menemukan bahwa kompleksitas persoalan yang dihadapi perempuan nelayan berlapis-lapis mulai dari level keluarga, masyarakat, komunitas dan pasar. Persoalan pembagian kerja, birokrasi yang bias serta kekerasan dalam rumah tangga adalah tiga topik utama yang dikaji dalam tulisan ini. Pengakuan terhadap identitas perempuan nelayan menjadi urgensi dan langkah awal yang harus diwujudkan guna memperbaiki kondisi perempuan nelayan.

Kata kunci: eksistensi perempuan nelayan, perempuan melaut, morodemak, purworejo, tambak polo, KDRT perempuan nelayan.

Naufaludin Ismail (Jurnal Perempuan, Jakarta, Indonesia)

Perjuangan Rekognisi Identitas Hukum Perempuan Nelayan Ujung Pangkah, Gresik: Analisis Feminis terhadap Kebijakan Kartu dan Asuransi Nelayan
Struggle of Legal Identity Recognition of Fisherwomen in Ujung Pangkah, Gresik: Feminist Analysis toward Regulation on Fishermen Card and Insurance

DDC: 305

Jurnal Perempuan, Vol. 22 No. 4, November 2017, hal. 311-321, 2 tabel, 10 daftar pustaka

This paper will focus on feminist analysis of Law No. 7 of 2016 on the Protection and Empowerment of Fishermen, Fish Cultivators and Salt Farmers and Regulation of the Minister of Marine Affairs and Fisheries No. 16 of 2016 as the legal basis for policy on Fishermen Card and Insurance. This paper will also analyze the experiences of two fisherwomen in Ujung Pangkah, Gresik, East Java who successfully obtained legal identity in the form of fisher card and insurance as a form of legitimacy and recognition of their identity as fisherwomen. The strong patriarchal culture in various society layers, caused the recognition of the political identity of fisherwomen has become difficult, so a feminist analysis toward policy on fisher card and insurance is needed so that women can engage as active subjects in the policy.

Keywords: fisherwomen, patriarchy, sexism, legal identity, feminist policy

Tulisan ini akan berfokus pada analisis feminis pada Undang-Undang (UU) Nomor 7 Tahun 2016 tentang Perlindungan dan Pemberdayaan Nelayan, Pembudidaya Ikan dan Petambak Garam dan Peraturan Menteri Kelautan dan Perikanan Nomor 16 tahun 2016 sebagai landasan hukum untuk kebijakan Kartu dan Asuransi Nelayan. Tulisan ini juga akan menganalisis pengalaman dua perempuan nelayan di Ujung Pangkah, Gresik, Jawa Timur yang berhasil mendapatkan akses identitas hukum berupa kartu dan asuransi nelayan sebagai bentuk legitimasi dan rekognisi identitas politik mereka sebagai perempuan nelayan. Kuatnya budaya patriarki di berbagai lapisan sosial-masyarakat menyebabkan pengakuan atas identitas hukum perempuan nelayan menjadi sulit untuk direkognisi, sehingga diperlukan sebuah analisis feminis atas kebijakan kartu dan asuransi nelayan agar perempuan bisa terlibat sebagai subjek aktif di dalam kebijakan tersebut.

Kata Kunci: perempuan nelayan, patriarki, seksisme, identitas hukum, kebijakan feminis

Ma. Linnea Villarosa-Tanchuling (College of Social Work and Community Development University of the Philippines Diliman, Metro Manila, Filipina)

Perempuan dalam Sektor Perikanan Berbasis Gender: Peran, Isu dan Tantangan di Kamboja, Indonesia, Vietnam dan Filipina

\section{Women in Gendered Fisheries: Roles, Issues and Challenges in Cambodia, Indonesia, Vietnam and Philippines}

DDC: 305

Jurnal Perempuan, Vol. 22 No. 4, November 2017, hal. 323-331, 1 tabel, 7 daftar pustaka

This paper is a synthesis of the results of the case studies on women's situation in fisheries done by the members of the SEA Fish for Justice Network. The network is composed of 15 non-government and fishers organizations from the Southeast Asia region. It envisions equity in access to and control over off-shore, coastal and inland aquatic natural resources including the termination of suffering caused by unsustainable resources and/or privatized control over communal resources. The case 
studies were conducted by SEAFish Network members in Cambodia, Indonesia, Vietnam and Philippines in the second and third quarter of 2008 to highlight the roles, issues and challenges faced by women in coastal communities as well as the spaces provided them to facilitate their empowerment. The network members who conducted the studies were FACT (Cambodia), KIARA (Indonesia), MCD (Vietnam) and PROCESS-Bohol, CERD, and Tambuyog Development Center (CERD).

\section{Keywords: women roles, women's participation, division of labor}

Artikel ini merupakan sintesis dari hasil studi kasus pada perempuan dalam industri perikanan yang dilakukan oleh anggota SEA FISH for Justice Network. Jaringan ini terdiri dari 15 organisasi nonpemerintah dan nelayan dari kawasan Asia Tenggara. Jaringan ini mengupayakan keadilan dalam akses dan kontrol atas sumber daya alam lepas pantai, pesisir dan darat, termasuk penghentian krisis yang disebabkan oleh sumber daya yang tidak berkelanjutan dan/atau privatisasi atas kontrol sumber daya yang bersifat publik. Penelitian dilakukan oleh anggota SEAFish Network di Kamboja, Indonesia, Vietnam dan Filipina pada kuartal kedua dan ketiga tahun 2008 untuk menyoroti peran, isu dan tantangan yang dihadapi perempuan di masyarakat pesisir, serta ketersediaan ruang untuk mempermudah usaha pemberdayaan perempuan. Anggota jaringan yang melakukan penelitian adalah FACT (Cambodia), KIARA (Indonesia), MCD (Vietnam) dan PROCESS-Bohol, CERD, dan Tambuyog Development Center (CERD).

Kata kunci: peran perempuan, partisipasi perempuan, pembagian kerja

Endah Kusuma Wardhani (Program Studi Kajian Gender Universitas Indonesia, Indonesia)

\section{Reklamasi Teluk Jakarta, Pemiskinan dan Marginalisasi Perempuan Nelayan: Studi Kasus di Kampung Akuarium dan Kamal Muara, Penjaringan}

\section{Reclamation of Jakarta Bay, Impoverishment and Marginalization of Fisherwomen: Case Study at Akuarium and Kamal Muara Village, Penjaringan}

DDC: 305

Jurnal Perempuan, Vol. 22 No. 4, November 2017, hal. 333-344, 13 daftar pustaka

It has been more than ten years since The Jakarta Bay reclamation project displaced fishermen from the sea where they were normally fishing. The direct impact of reclamation on fisherwomen was income decrease, because it has damaged the marine ecosystems due to the effects of sucking and backfilling of the sea sand. In addition, there will be at least 16,998 of fishermen households will be evicted from the coastal areas of Jakarta, Banten and Bekasi due to this reclamation. The findings of this study are: the reclamation made the fisherwomen become poorer, their burden is higher and they have experienced double marginalization. The research methodology is a qualitative study with feminist perspective. Data collection are by in-depth interview with ten fisherwomen, document study, and fields observation. Selection of research sites is purposive, namely Kampung Akuarium dan Kampung Kamal Muara, District of Penjaringan, North Jakarta Municipality. In particular, this study wants to bring up the voices of poor fisherwomen as marginalized group of people, who have not been heard. It is hoped they will be brave and voiced their rights and aspirations openly which they have not dared to do so.

Keywords: fisherwomen, Jakarta Bay reclamation, marginalization, fisherwomen impoverishment

Proyek reklamasi Teluk Jakarta setidaknya telah lebih dari sepuluh tahun menggusur para nelayan dari wilayah perairan yang merupakan sumber penghidupan mereka. Dampak reklamasi secara langsung pada perempuan nelayan adalah penurunan pendapatan karena ekosistem laut sedemikian rupa hancur akibat penghisapan dan pengurukan pasir laut. Selain itu, setidaknya terdapat 16.998 rumah tangga nelayan akan tergusur dari wilayah pesisir Jakarta, Banten dan Bekasi akibat proyek reklamasi ini. Temuan dari penelitian ini adalah tenjadinya penurunan pendapatan, beban kerja perempuan nelayan yang makin besar, dan makin termarginalisasinya para perempuan nelayan. Metodologi penelitian ini bersifat kualitatif berperspektif feminis. Teknik pengumpulan data berupa wawancara mendalam kepada sepuluh perempuan nelayan, studi dokumen, dan observasi di lapangan. Pemilihan lokasi penelitian bersifat purposif, yaitu di Kampung Akuarium, Kelurahan Penjaringan, Kecamatan Penjaringan, Kotamadya Jakarta Utara. Secara khusus, penelitian ini ingin memunculkan suara-suara perempuan nelayan miskin sebagai kaum marginal perkotaan, yang selama ini tidak terdengar. Diharapkan mereka kemudian berani bersikap dan menyuarakan hak dan aspirasi secara terbuka yang selama ini belum berani mereka lakukan.

Kata kunci: perempuan nelayan, reklamasi Teluk Jakarta, marginalisasi perempuan nelayan, pemiskinan perempuan nelayan

Yekti Wahyuni (Program Studi Kajian Gender, Sekolah Kajian

Stratejik dan Global, Universitas Indonesia, Indonesia)

\section{Peran Produksi, Reproduksi dan Sosial Kemasyarakatan Perempuan Pengolah Kerang Hijau di Muara Angke, Jakarta Utara}

\section{Productive, Reproductive and Community Roles of Women Who Process Green Shells in Muara Angke, North Jakarta}

DDC: 305

Jurnal Perempuan, Vol. 22 No. 4, November 2017, hal. 345-357, 2 gambar, 1 tabel, 13 daftar pustaka

This study aims to find out the productive, reproductive and community roles of fisherwomen in Muara Angke, Kecamatan Penjaringan, North Jakarta. The subjects of the study were two fisherwomen who work in the processing of green shells, as owners and as shell-peeler laborer. The study explores women's experience as breadwinners in the marine sector including the experience as a catch fisherwomen. The results showed that the role of fisherwomen in the productive and improvement of the family economy is very real, either directly or indirectly as a fisherwomen or processor of marine products. Three roles of fisherwomen in Muara Angke, sub-district Penjaringan, North Jakarta namely productive, reproductive, and social community. The fisherwomen took part in supplementing family income. In addition to performing reproductive roles related to domestic work, fisherwomen also have an active social role in social movements in order to maintain their living spaces and their spheres. The study found the tendency of women to abandon the role of capture fisherwomen when carrying out the role of biological reproduction.

Keywords: fisherwomen, economic roles, social roles, production roles, reproductive roles, social community roles

Penelitian ini bertujuan untuk mengetahui peran produksi, reproduksi dan sosial kemasyarakatan perempuan nelayan di Muara Angke, Kecamatan Penjaringan, Jakarta Utara. Subjek penelitian adalah dua orang perempuan nelayan yang bekerja di bidang pengolahan kerang hijau, sebagai pemilik dan sebagai buruh pengupas kerang. Penelitian menggali pengalaman perempuan sebagai pencari nafkah di sektor kelautan termasuk pengalaman sebagai nelayan tangkap. Hasil penelitian menunjukkan bahwa peran perempuan nelayan dalam produksi dan peningkatan ekonomi keluarga sangatlah nyata, baik secara langsung maupun tidak langsung sebagai nelayan maupun pengolah hasil laut. Tiga peran perempuan nelayan di Muara Angke, Kecamatan Penjaringan, Jakarta Utara yakni produksi, reproduksi, dan sosial kemasyarakatan. Perempuan nelayan ikut ambil bagian dalam menambah pendapatan keluarga. Selain menjalankan peran reproduksi yang berkaitan dengan pekerjaan rumah tangga, perempuan nelayan juga memiliki peran sosial kemasyarakatan dengan aktif dalam gerakan sosial dalam upaya mempertahankan ruang hidup dan ruang kelolanya. Penelitian menemukan kecenderungan perempuan meninggalkan 
peran sebagai nelayan tangkap ketika menjalankan peran reproduks biologis.

Kata kunci: perempuan nelayan, peran ekonomi, peran sosial, peran produksi, peran reproduksi, peran sosial kemasyarakatan

Gadis Arivia \& Abby Gina (Jurnal Perempuan, Jakarta Indonesia)

Kapabilitas Manusia untuk Pembangunan yang Berkeadilan: Studi Kasus Perempuan Petambak Udang di Dipasena, Lampung

\section{Human Capabilities for Fair Development: Case Study of Women Prawn Farmers in Dipasena, Lampung}

DDC: 305

Jurnal Perempuan, Vol. 22 No. 4, November 2017, hal. 359-368, 4 tabel, 5 daftar pustaka

This study examines the role of women prawn farmers in Dipasena, East Rawajitu District, Tulang Bawang, Lampung and what it means for human development in Indonesia. Several focus group discussions and indepth interviews with women prawn farmers and fishermen community were conducted to collect data and understand comprehensively the issues that women prawn farmers face in a patriarchal culture where they are not acknowledged as women workers. This paper uses a feminist perspective on women and work and Martha Nussbaum's capability categories. This paper concludes that women's roles and contribution in fishery and in national development is not recognized and not accommodated in national and local policies. Women's role in fishery industry is considered non-existent in this society and therefore restrict their potential and meaningful existence and respect on equal human dignity.

Keywords: women prawn farmers, capabilities, human dignity, development, Martha Nussbaum

Penelitian ini melihat peran perempuan petambak udang di Dipasena, Kabupaten Rawajitu Timur, Tulang Bawang, Lampung dan melihat apa dampaknya pada pembangunan manusia di Indonesia. Beberapa diskusi kelompok terarah dan wawancara mendalam dengan para petambak perempuan dan komunitas nelayan dilakukan untuk pengumpulan data guna memahami secara komprehensif persoalanpersoalan yang dihadapi perempuan petambak di dalam masyarakat patriarki, di mana mereka tidak diakui sebagai petambak perempuan. Tulisan ini menggunakan perspektif feminis tentang perempuan dan kerja dan pendekatan kapabilitas dari Martha Nussbaum. Tulisan ini menyimpulkan bahwa peran dan kontribusi perempuan dalam perikanan dan pembangunan nasional tidak diakui dan tidak diakomodasi dalam kebijakan nasional dan daerah. Peran perempuan dalam industri perikanan tidak diakui dalam masyarakat sehingga membatasi eksistensi mereka yang potensial dan bermakna serta membatasi penghargaan atas kesetaraan manusia.

Kata Kunci: perempuan petambak udang, kapabilitas, kemartabatan manusia, pembangunan, Martha Nussbaum 
viii Perempuan 


\title{
Kapabilitas Manusia untuk Pembangunan yang Berkeadilan: Studi Kasus Perempuan Petambak Udang di Dipasena, Lampung
}

\author{
Human Capabilities for Fair Development: \\ Case Study of Women Prawn Farmers in Dipasena, Lampung
}

\author{
Gadis Arivia \& Abby Gina \\ Jurnal Perempuan \\ gadisarivia@gmail.com \& abbygina@jurnalperempuan.com
}

Kronologi Naskah: diterima 27 September 2017, direvisi 7 Oktober 2017, diputuskan diterima 14 Oktober 2017

\begin{abstract}
This study examines the role of women prawn farmers in Dipasena, East Rawajitu District, Tulang Bawang, Lampung and what it means for human development in Indonesia. Several focus group discussions and indepth interviews with women prawn farmers and fishermen community were conducted to collect data and understand comprehensively the issues that women prawn farmers face in a patriarchal culture where they are not acknowledged as women workers. This paper uses a feminist perspective on women and work and Martha Nussbaum's capability categories. This paper concludes that women's roles and contribution in fishery and in national development is not recognized and not accommodated in national and local policies. Women's role in fishery industry is considered non-existent in this society and therefore restrict their potential and meaningful existence and respect on equal human dignity.
\end{abstract}

Keywords: women prawn farmers, capabilities, human dignity, development, Martha Nussbaum

\begin{abstract}
Abstrak
Penelitian ini melihat peran perempuan petambak udang di Dipasena, Kabupaten Rawajitu Timur, Tulang Bawang, Lampung dan melihat apa dampaknya pada pembangunan manusia di Indonesia. Beberapa diskusi kelompok terarah dan wawancara mendalam dengan para petambak perempuan dan komunitas nelayan dilakukan untuk pengumpulan data guna memahami secara komprehensif persoalan-persoalan yang dihadapi perempuan petambak di dalam masyarakat patriarki, di mana mereka tidak diakui sebagai petambak perempuan. Tulisan ini menggunakan perspektif feminis tentang perempuan dan kerja dan pendekatan kapabilitas dari Martha Nussbaum. Tulisan ini menyimpulkan bahwa peran dan kontribusi perempuan dalam perikanan dan pembangunan nasional tidak diakui dan tidak diakomodasi dalam kebijakan nasional dan daerah. Peran perempuan dalam industri perikanan tidak diakui dalam masyarakat sehingga membatasi eksistensi mereka yang potensial dan bermakna serta membatasi penghargaan atas kesetaraan manusia.
\end{abstract}

Kata Kunci: perempuan petambak udang, kapabilitas, kemartabatan manusia, pembangunan, Martha Nussbaum

\section{Pendahuluan}

Lagu instrumental klasik yang lembut diputar oleh Bapak Tanjung, salah seorang pejabat di P3UW (Perhimpunan Petambak Pengusaha Udang Wilayah) Lampung, mengiringi perjalanan kami ke bumi Dipasena, Kecamatan Rawajitu Timur, Kabupaten Tulang Bawang, Lampung. Perjalanan sepanjang 207,5 km itu memakan waktu 8 jam dari bandara Lampung via Jl. Lintas Timur Sumatera. Meskipun lagu-lagu yang diputar sepanjang jalan tenang tapi tidak demikian dengan keadaan kami di dalam mobil. Lagu yang bisa menggambarkan suasana hati kami mungkin lebih tepat dikatakan lagu goyang dangdut atau kata orang Dipasena "goyang Inul". Meskipun jalanan rusak berat, tidak menghalangi semangat kami ke bumi Dipasena yang di pertengahan tahun 1990-an begitu harum namanya.
Dipasena pernah mengalami masa kejayaan. Pada tahun 1997 PT Dipasena menjadi tambak udang terbesar di Asia Tenggara bahkan di dunia. Pertambakan tersebut luasnya 16.250 hektar dan melibatkan 9.033 petambak plasma dengan 11 ribu lebih karyawan (Fadilasari 2007 , h. 1). PT Dipasena Citra Darmaja milik pengusaha Sjamsul Nursalim memopulerkan Dipasena di kalangan pelaku bisnis internasional dan berhasil memasukkan devisa negara sebesar 167 juta dolar AS di tahun 1998. Keberhasilan dalameksporudang ini meraih penghargaan ekspor Primanyarta 1995, 1996, 1997. Namun di awal tahun 2000-an, pertambakan udang Dipasena mati. Pihak perusahaan melakukan kesewenang-wenangan, manajemen tidak transparan, memaksakan kehendak dan mengekang kebebasan (Fadilasari 2007, h. 2). Pemberontakan petambak udang memuncak dan terjadi 
kerusuhan peristiwa 1 Maret 2000 ketika konglomerat Sjamsul Nursalim menginstruksikan pengawalnya yang merupakan anggota Brimob melakukan penembakan. Salah seorang petambak bernama Ruswandi tertembak dan terluka. Situasi kemudian tidak terkendali dan Sjamsul Nursalim melarikan diri ke luar negeri.

Pemulihan terhadap bumi Dipasena setelah itu tidak berjalan mulus. Aset Dipasena dijual murah oleh pemerintah kepada Konsorsium Neptune yang seharusnya $\mathrm{Rp}$ 2,3 triliun namun hanya diwajibkan membayar Rp 668 miliar dan penjualan tersebut termasuk penjualan fasilitas umum. CP Prima, anggota konsorsium Neptune mendirikan PT Aruna Wijaya Sakti untuk mengelola Dipasena melalui konsep kemitraan dengan petambak udang. Namun di dalam perjalanannya konsep kemitraan tersebut menimbulkan persoalan lagi dan petambak udang menghendaki berdiri sendiri. Sementara itu dengan tidak adanya kerjasama dengan pihak perusahaan, Dipasena semakin terpuruk karena listrik dicabut dan perawatan jalan terbengkalai serta ketua P3UW, Nafian Faiz sempat dipenjara selama dua setengah tahun. Pada tanggal 3 Agustus 2011, para petambak udang Dipasena benar-benar menghendaki putus hubungan dengan perusahaan dan memilih mandiri. Dipasena ditetapkan sebagai minapolitan ${ }^{1}$ di zaman pemerintahan Susilo Bambang Yudhoyono, menjadi petambak yang mandiri dan tidak perlu lagi bermitra dengan perusahaan yang cenderung memonopoli harga, mark-up anggaran, "kredit macet", dan memutuskan hubungan kerja dengan petambak secara sewenang-wenang.

Kemandirian petambak udang Dipasena membawa pengaruh yang positif. Mereka berhasil mengelola sendiri pertambakan udang meskipun dengan susah payah dan usaha mereka terbayar dengan penghasilan yang sangat lumayan. Buku Fadilasari (2007) yang menggambarkan konflik Dipasena selama 22 tahun diakhiri pada pentingnya mencapai kemitraan berlandaskan HAM dengan merujuk pada Konvensi Hak Ekonomi, Sosial dan Budaya (Ekosob), yang telah diratifikasi oleh Indonesia tahun 2005. Komnas HAM pada tahun 2011 juga menggarisbawahi pentingnya landasan HAM dalam kemitraan dan mendukung penuh pemberdayaan masyarakat petambak udang.

Sayangnya buku Fadilasari tidak menceritakan peran petambak udang perempuan. Petambak udang diasumsikan berjenis kelamin laki-laki. Memang PT Dipasena dan PT Aruna Wijaya Sakti menganggap petambak adalah laki-laki. ${ }^{2}$ Bahkan Haeru Rahayu, asisten bidang pendidikan dan pelatihan maritim, Kementerian
Koordinator Kemaritiman (2016 dikutip dalam Artharini 2016, para 11), dengan tegas menganggap perempuan belum bisa turun ke laut dan lebih penting peranannya sebatas pendukung suami.

Pernyataan pejabat publik mengenai peran nelayan perempuan, khususnya di dalam artikel ini soal petambak perempuan, mencemaskan. Mengapa petambak perempuan tidak diakui profesinya? Apakah mereka sendiri ingin diakui? Konsep pembangunan yang bagaimanakah yang seharusnya dijalankan oleh pemerintah? Tulisan ini berupaya menjawab pertanyaanpertanyaan tersebut dengan cara mewawancarai para petambak perempuan di Dipasena, Lampung, serta menganalisisnya dengan perspektif feminisme khususnya menggunakan kerangka pemikiran Martha Nussbaum tentang kapabilitas.

\section{Pendekatan Kapabilitas}

Pendekatan kapabilitas pertama kali digunakan oleh seorang ekonom dan filsuf dari India, Amartya Sen di tahun 1980-an. Pemikiran Sen tentang kapabilitas diakui oleh PBB (Perserikatan Bangsa-Bangsa) sebagai definisi pembangunan yang seutuhnya sebab tidak mengukur pembangunan semata-mata dari segi metrik ekonomi, misalnya dari segi pertumbuhan PDB (Produk Domestik Bruto) per kapita, tetapi lebih luas dari itu. Dalam pemikiran Sen, "kemiskinan" dipahami sebagai hambatan untuk mencapai kehidupan yang baik, jadi "pembangunan" dimaksudkan sebagai meluaskan kapabilitas seseorang agar seseorang dapat hidup dengan bahagia dan bertumbuh kembang (flourishing). ${ }^{3}$ Sen (yang juga pemenang hadiah nobel tahun 1998) menuangkan buah pemikirannya tentang kapabilitas di dalam bukunya yang terkenal berjudul Development as Freedom (1999). la berangkat dari titik tolak kebebasan.

Development has to be more concerned with enhancing
the lives we lead and the freedoms we enjoy. Expanding
the freedoms that we have reason to value not only
makes our lives richer and more unfettered, but also
allows us to be fuller social persons, exercising our own
volitions and interacting with-and influencing-the world
in which we live in. (Sen 1999, h. 363).

Titik tolak Sen adalah kebebasan manusia. Sebab baginya pembangunan tidak semata-mata soal pertumbuhan ekonomi melainkan memerhatikan semua aspek kehidupan manusia termasuk kebebasankebebasan yang kita inginkan. Sen mempertimbangkan aspek nilai hidup manusia dan bagaimana kehidupan sosial seseorang dapat terpenuhi secara utuh menurut 
keinginan diri masing-masing. Kebebasan bergantung pada determinasi lainnya seperti pengaturan sosial dan ekonomi (misalnya fasilitas pendidikan dan kesehatan), dan termasuk hak-hak politik dan sipil (misalnya kebebasan untuk berpartisipasi dalam diskusi dan kegiatan publik serta bersikap kritis) (Sen 1999, h. 179). Pembangunan maksudnya di sini, adalah proses untuk meluaskan kebebasan yang ingin dinikmati manusia. Artinya, pembangunan juga bertujuan menghilangkan sumber-sumber ketidakbebasan: kemiskinan dan termasuk tirani, kesempatan ekonomi yang minim termasuk pemiskinan sosial, fasilitas yang diabaikan, intoleransi atau penindasan yang dilakukan oleh negara. Ketidakbebasan termasuk juga ketiadaan kepedulian pemerintah terhadap fasilitas publik dan sosial, tidak adanya program-program kesehatan. Soal fasilitas publik yang minim di Dipasena dikeluhkan oleh ibuibu Dipasena yang merasa kerusakan jalan yang berat telah mengganggu akses kesehatan terutama masalahmasalah kesehatan reproduksi.

Ya punya anak tiga ya. Satu meninggal. Karena posisi kita jauh dari sini ke dokter. Saya periksa ke dokter, katanya ya harus segera, tapi di sini RS tidak ada ya, cuma ada puskesmas dan bidan. Saya harus segera ke luar ke Bandar Lampung, harus cesar. Dua belas jam perjalanan, karena posisi saya waktu itu sedang hamil besar, gak bisa cepat-cepat. Takutnya bener kejadian, tadinya posisi anak saya sudah bagus, karena perjalanan jelek, posisinya jadi melintang anak itu. Dokternya datang, saya minta operasi. Saya sudah tidak tahan lagi. Di situ saya sudah tahu anak saya sudah gak ada lagi, sudah gak gerak. Langsung lah di cesar. Posisi anak sudah tidak ada lagi. Saya dua kali operasi saat itu, pertama lahir anak keluar, kedua rahim dibuang. Semua dibuang. Akhirnya sekarang saya menopause dini (Ida 2017, wawancara 26 Agustus).

Pendekatan kapabilitas menggugat pembangunan yang menggunakan pemahaman utilitarian, yaitu pembangunan memaksimalkan utilitas untuk manfaat orang banyak. Tetapi juga mengkritik pemahaman Rawlsian yang menganjurkan intervensi pemerintah dalam pembangunan untuk memenuhi kebutuhan dasar masyarakat (berangkat dari teori keadilan). Argumentasi Sen menurut saya lebih superior dari kedua pemahaman tersebut, Sen menekankan soal kualitas hidup manusia bukan semata-mata memenuhi kebutuhan dasar masyarakat. Namun menurut saya pemahaman Sen pun belum memadai untuk melihat kasus ibu Ida di atas yang menjelaskan bukan saja soal kebutuhan pelayanan kesehatan yang memadai tetapi ada dimensi gender soal kesehatan reproduksi. Di sinilah Martha Nussbaum mengajukan teori kapabilitas-kapabilitas (plural) karena melihat pendekatan kapabilitas harus dimaknai secara plural. Artinya, persoalan ibu Ida bukan saja persoalan kapabilitasnya (kualitas hidupnya) yang terhambat karena tidak terpenuhinya pelayanan publik seperti rumah sakit di Dipasena, tetapi ada keterkaitan dengan ketidakpedulian kesehatan reproduksi atau kesehatan perempuan dari pihak masyarakat dan pemerintah.

Kapabilitas menurut Nussbaum berhubungan dengan kemartabatan manusia dan kemartabatan keadilan. Kapabilitas mengajukan dua pertanyaan penting, "Apakah yang bisa dilakukan oleh setiap orang dan bisa menjadi apakah setiap orang?" Dua soal to do dan to be adalah dua soal yang berhubungan dengan kemartabatan manusia. Dengan kata lain, "setiap orang dipandang sebagai hasil akhir", bukan saja soal kesejahteraannya (fisik) tetapi soal kesempatan yang dapat diraih oleh setiap orang. Fokusnya pada pilihan dan kebebasan, bisa saja seseorang tidak menggunakan hak pilihnya tetapi kesempatan dan kebebasan untuk memilih itu tersedia. Artinya, ada komitmen menghargai manusia untuk menentukan dirinya sendiri (Nussbaum 2011, h. 18).

Nussbaum membedakan kapabilitas internal dan kapabilitas kombinasi. la menganggap bahwa bisa saja masyarakat memiliki kapabilitas internal, misalnya disediakan fasilitas pendidikan untuk mendidik mereka agar bisa berpendapat dan berekspresi-kapabilitas internal-tetapi praktiknya mereka dilarang untuk berpendapat dan berekspresi secara bebas. Pelarangan ini bisa saja dibatasi oleh negara tetapi juga oleh budaya, dalam kasus isu gender, budaya patriarki mengekang perempuan untuk berpendapat, hanya laki-laki yang lazim didengarkan pendapat-pendapatnya dan yang sering berbicara di depan publik. Setiap orang secara internal dapat berpartisipasi di dalam politik (dibolehkan oleh pemerintah) tetapi dalam kapabilitas kombinasi, mereka tidak mungkin melakukannya karena mereka etnis minoritas atau penduduk ilegal misalnya. Bisa saja seseorang dalam kapabilitas internalnya boleh mengkritik pemerintah tetapi tidak memiliki kemampuan untuk berpikir secara kritis atau mampu berbicara di depan umum (Nussbaum 2011, h. 22). Ketidakmampuan seseorang tersebut bukan karena secara inheren orang tersebut tidak mampu (dari sononya begitu) tetapi karena tidak disediakan kesempatan yang luas untuk orang bertumbuh kembang (flourishing). 
Tabel 1: Kapabilitas

$\begin{array}{ll}\text { Kapabilitas Internal: } & \begin{array}{l}\text { Kapabilitas internal berangkat dari kapabilitas dasar manusia yang sudah ada misalnya } \\ \text { adanya pendidikan dasar, pelatihan, pengalaman, dan sebagainya. }\end{array} \\ \text { Kapabilitas Kombinasi: } & \begin{array}{l}\text { Kapabilitasinternal plus. Kondisieksternalyang dapatmembuatmanusiaberfungsisecara } \\ \text { menyeluruh dalam kehidupannya. Tujuan kebijakan publik adalah mempromosikan } \\ \text { kapabilitas kombinasi dengan cara: (1) menyediakan kapabilitas internal (pendidikan, } \\ \text { pelatihan) dan (2) memastikan institusi-institusi eksternal mendukung fungsi kehidupan } \\ \text { manusia secara utuh termasuk mendukung kondisi materialnya. }\end{array}\end{array}$

Sumber: Diolah dari Nussbaum (2011)

Bila kita kembali kepada pernyataan Haeru Rahayu, asisten bidang pendidikan dan pelatihan maritim, Kementerian Koordinator Kemaritiman pada tahun 2016, yang menyatakan bahwa perempuan belum bisa menjadi nelayan, hal ini menunjukkan adanya hambatan dari pemerintah mengakui kemampuan perempuan menjadi apa yang dia inginkan, yaitu, menjadi perempuan nelayan. Di dalam kasus ini baik kapabilitas internal maupun kombinasi perempuan diabaikan. Secara kapabilitas internal, pemerintah tidak menjamin pengakuan perempuan sebagai nelayan (baik di definisi peraturan pemeritah maupun minimnya pembagian kartu nelayan untuk perempuan) dan juga secara kapabilitas kombinasi, perempuan tidak diberikan akses untuk diakui sebagai nelayan perempuan. Padahal, ketua P3UW, Nafian Faiz mengakui bahwa peran ibu-ibu petambak udang memang besar bagi Dipasena. Mereka bukan hanya membantu suami menambak tetapi mereka benar-benar adalah petambak.

Kegiatan ibu-ibu Dipasena hampir 80\% di tambak dan orang-orang tidak percaya. Di Jawa, tambak jauh dari rumah tinggal. Tambak ya tambak, rumah ya rumah.
Kalau kita, tambaknya di depan rumah. Oleh karena kegiatan ibu-ibunya dari bangun hingga tidur ya di tambak itulah, bahkan kadang mengalahkan bapakbapaknya. Kalau bahasanya, cuma satu saja yang tidak dilakukan oleh ibu-ibunya, yaitu Nyipon. Nyipon itu adalah membuang lumpur. Bahkan sekarang, ada ya ibu-ibu yang bisa buang lumpur. Terjun ke dalam tambak dengan ketinggian air $100 \mathrm{M}$, buang lumpur dan ini tidak dilakukan oleh perempuan-perempuan petambak di luar sana, oleh karena itu kawan-kawan di luaran kaget saat kita cerita. Belum lagi soal keberanian ibu-ibu, di mana ibu-ibu petambaknya berbeda dari sisi pengetahuan, keberanian dan lainnya dibanding dari ibu petambak lainnya. Kita yang jadi petambak di sini adalah orang yang hasil lulus seleksi tentu ibuibunya juga yang lulus seleksi gitu kan (Faiz 2017, FGD 26 Agustus).

Ibu-lbu petambak udang PPNI (Persaudaraan Perempuan Nelayan Indonesia) Bareta (Barisan Relawan Wanita) Dipasena berkumpul di hari Sabtu, 26 Agustus 2017 dengan semangat untuk mengikuti focus group discussion (FGD). FGD dibuka oleh Ibu Khotijah, ketua PPNI, Bareta. Perwakilan yang datang sekitar total 20 orang terdiri dari 8 kampung:

\section{Tabel 2: Partisipan FGD}

\begin{tabular}{lll} 
No & Nama & Perwakilan \\
\hline 1 & Ibu Ezra Dwi Lestari & Bumi Dipasena Agung (Blok 4-5) \\
\hline 2 & Ibu Sukamti & Bumi Dipasena Abadi (Blok 14-15) \\
\hline 3. & Ibu Sumarsih & Bumi Dipasena Sejahtera (Blok 12-13) \\
\hline 4. & Ibu Theresia & Bumi Dipasena Makmur (Blok 10-11) \\
\hline 5. & Ibu Haeni & Bumi Dipasena Mulia (Blok 8-9) \\
\hline 6. & Ibu Lamian & Bumi Dipasena Jaya (Blok 6-7) \\
\hline 7. & Ibu Sri Wedati & Bumi Dipasena Utama (Blok 2-3) \\
8. & Ibu Yuliana & Bumi Dipasena Sentosa (Blok 0-1) \\
\hline
\end{tabular}

Sumber: data lapangan, Agustus 2017

Ibu-ibu bercerita tentang kegiatan mereka yang sangat padat sebagai petambak udang. Mereka mengklaim bekerja lebih dari 17 jam sehari karena saat malam pun harus terjaga bila mesin mati. Pekerjaan sebagai petambak udang di Dipasena sangat sulit apalagi aliran listrik belum ada (sebab diputus perusahaan ketika perusahaan hengkang dan PLN belum hadir), jadi mereka menggunakan generator. Bila mesin mati hampir 
bisa dipastikan semua udang mati, artinya gagal panen. Dalam kegiatan FGD ini, Ibu-ibu dibagi tiga kelompok menyampaikan kegiatan mereka sehari-hari. Di dalam teori feminisme, yang disebut bekerja bukan saja nilai kerja di ruang publik namun juga di ruang privat. Pekerjaan perempuan tidak bisa dilihat hanya di bidang produktivitas di ranah publik saja tetapi juga harus diukur secara keseluruhan termasuk di ranah privat. Pemisahan antara ranah publik dan privat dipandang feminisme sebagai diskriminasi. Budaya patriarki memberikan nilai lebih pada pekerjaan publik dan tidak melihat pekerjaan domestik dan reproduksi (melahirkan, menyusui, merawat anak) sebagai yang bernilai. Dikotomi publik dan privat melahirkan kebijakan-kebijakan publik yang seksis. Nussbaum mengkritik cara berpikir yang tidak memedulikan pekerjaan yang berkontribusi pada perawatan keluarga dan tidak melihat ketidaksetaraan yang terjadi akibat pendikotomian ruang publik dan privat. Akibatnya, negara tidak memedulikan aktivitas ruang privat dan tidak membuat kebijakan berdasarkan pertimbangan nilai ruang privat (Nussbaum 1999, h. 61$62)$.

Jelas sekali kegiatan ibu-ibu Dipasena sebagai petambak melibatkan kegiatan di ranah privat. Tiga kelompok ibu-ibu diminta untuk memetakan kegiatan menambak mereka, semua memasukkan unsur pekerjaan domestik di dalamnya.

Tabel 3: Kegiatan Petambak Perempuan

\begin{tabular}{|c|c|c|c|c|}
\hline Jam & Kelompok 1 & Kelompok 2 & Kelompok 3 & Catatan \\
\hline 4.30 & $\begin{array}{l}\text { Bersih-bersih rumah, } \\
\text { salat subuh. }\end{array}$ & $\begin{array}{l}\text { Bersih-bersih rumah, } \\
\text { salat subuh. }\end{array}$ & $\begin{array}{l}\text { Ke dapur menyiapkan } \\
\text { sarapan, buat kopi } \\
\text { suami. }\end{array}$ & \\
\hline $6.00-6.30$ & $\begin{array}{l}\text { Menyiapkan makan } \\
\text { anak-anak dan kopi } \\
\text { suami. }\end{array}$ & $\begin{array}{l}\text { Menyiapkan makan } \\
\text { anak-anak dan kopi } \\
\text { suami. }\end{array}$ & $\begin{array}{l}\text { Antar anak-anak } \\
\text { sekolah. Kasih pakan } \\
\text { udang. }{ }^{4}\end{array}$ & \\
\hline $8.00-9.00$ & $\begin{array}{l}\text { Antar anak-anak } \\
\text { sekolah, cek ancho. }\end{array}$ & $\begin{array}{l}\text { Antar anak-anak } \\
\text { sekolah, cek ancho. }\end{array}$ & & $\begin{array}{l}\text { Bapak melakukan } \\
\text { nyipon. }{ }^{6} \text { Ibu Sumarsih } \\
\text { nyipon sendiri karena } \\
\text { mengurus tambak } \\
\text { sendiri. }\end{array}$ \\
\hline $9.00-12.00$ & $\begin{array}{l}\text { Berkebun, jemput } \\
\text { anak-anak sekolah, } \\
\text { kasih pakan udang. }\end{array}$ & $\begin{array}{l}\text { Ikut kegiatan PPNI } \\
\text { misalnya merajut, buat } \\
\text { makanan dan kasih } \\
\text { pakan udang. }\end{array}$ & & $\begin{array}{l}\text { Suami kerja ke luar } \\
\text { karena tidak hanya } \\
\text { mengandalkan } \\
\text { tambak. Istri juga cari } \\
\text { tambahan misalnya } \\
\text { dagang. }\end{array}$ \\
\hline $12.30-16.00$ & $\begin{array}{l}\text { Salat, istirahat makan } \\
\text { siang dan olah raga } \\
\text { bersama. Menyiapkan } \\
\text { makan malam. }\end{array}$ & $\begin{array}{l}\text { Olah raga, kasih pakan } \\
\text { udang. Kasih makan } \\
\text { ternak bila ada ternak. }\end{array}$ & $\begin{array}{l}\text { Cek ancho, ke kegiatan } \\
\text { PPNI. }\end{array}$ & $\begin{array}{l}\text { Suami juga ikut } \\
\text { berolah raga voli atau } \\
\text { suami memancing } \\
\text { untuk tambahan. }\end{array}$ \\
\hline $18.00-21.00$ & $\begin{array}{l}\text { Salat Magrib, makan } \\
\text { malam, bantu anak } \\
\text { belajar. }\end{array}$ & $\begin{array}{l}\text { Menyiapkan makan } \\
\text { malam, bantu anak } \\
\text { belajar. }\end{array}$ & $\begin{array}{l}\text { Menyiapkan makan } \\
\text { malam, mengawasi } \\
\text { anak belajar dan kerja } \\
\text { rumah. }\end{array}$ & $\begin{array}{l}\text { Peran ibu di dalam } \\
\text { pendidikan anak- } \\
\text { anaknya sangat } \\
\text { menonjol terbukti } \\
\text { dengan } 80 \% \text { anak } \\
\text { petambak udang } \\
\text { Dipasena sekolah di } \\
\text { Perguruan Tinggi. }\end{array}$ \\
\hline $21.00-24.00$ & $\begin{array}{l}\text { Menemani anak-anak } \\
\text { tidur, dan menemani } \\
\text { suami jaga kincir. } \\
\text { Memikirkan masakan } \\
\text { untuk besok. Kasih } \\
\text { pakan udang. }\end{array}$ & $\begin{array}{l}\text { Jadi “hansip” udang, } \\
\text { periksa udang, periksa } \\
\text { kincir. }\end{array}$ & $\begin{array}{l}\text { Kasih pakan udang } \\
\text { bergantian dengan } \\
\text { suami. }\end{array}$ & \\
\hline
\end{tabular}




$\begin{array}{lllll}\text { Jam } & \text { Kelompok 1 } & \text { Kelompok 2 } & \text { Kelompok 3 } & \text { Catatan } \\ \text { 24.00-4.30 } & \begin{array}{l}\text { Tidur "ayam-ayam" } \\ \text { sambil cek mesin takut } \\ \text { bensin mati karena } \\ \text { tidak pakai listrik. }\end{array} & \begin{array}{l}\text { Bergantian tidur } \\ \text { "ayam-ayam" dan tetap } \\ \text { waspada. }\end{array} & \begin{array}{l}\text { Cek tambak bersama } \\ \text { suami, periksa kincir. }\end{array} & \begin{array}{l}\text { Udang harus dicek } \\ \text { apakah dia aktif atau } \\ \text { melayang-layang di } \\ \text { tengah. Bila melayang- } \\ \text { layang ada masalah. }\end{array} \\ & & & \begin{array}{l}\text { Atau ada biawak, } \\ \text { berang-berang, dsb. }\end{array}\end{array}$

Sumber: data lapangan, Agustus 2017

Bila diperhatikan dari tabel di atas, kegiatan petambak perempuan di Dipasena bercampur dengan kegiatan domestik yang juga merupakan beban pekerjaan mereka. Mereka bekerja secara profesional membudidayakan udang plus merawat keluarga. Artinya, tidak bisa dikatakan bahwa peran ibu-ibu Dipasena hanya sebagai pendukung suami dalam menambak udang, mereka secara bebas, sadar dan berpengetahuan menjadi petambak udang. Dalam setiap kegiatan dari pagi hingga pagi hari lagi mereka secara sadar dan bertanggung jawab menjaga udang. Bahkan pekerjaan mereka berlipat ganda seperti yang tergambarkan pada tabel di atas. Sisi lain dari kapabilitas adalah kemampuan menghasilkan (functioning). Functioning adalah merealisasikan kapabilitas. Functioning di sini bukan selalu bersifat aktif tetapi yang berhubungan dengan kesejahteraan (fisik maupun jiwa) si individu (Nussbaum 2011, h. 2526). Jadi, bila dari data kegiatan ibu-ibu petambak (tabel 3) menunjukkan bahwa mereka mengakui diri sebagai pekerja petambak udang, maka functioning petambak perempuan harus diperhatikan. Apakah kapabilitas petambak perempuan mampu menghasilkan kebahagiaan dirinya sebagai petambak? Kemampuan menghasilkan di sini bukan berarti materi belaka tetapi bahwa kemampuan menghasilkan melibatkan kemartabatan manusia. Nussbaum memberi contoh ada perbedaan besar antara membuat kebijakan yang mempromosikan kesehatan dan yang mempromosikan kapabilitas kesehatan, yang terakhir menghargai pilihanpilihan bebas seseorang. Kapabillitas kesehatan artinya mengakui kemartabatan manusia, menghargai pendapat dan eksistensi diri individu tersebut. Artinya, menghargai pula pluralitas, misalnya perbedaan agama, pandangan hidup, politik, gender, etnisitas, dan sebagainya.

\section{Kemartabatan Petambak Perempuan}

Kapabilitas berfokus pada kemartabatan manusia. Petambak perempuan di Dipasena ketika melakukan FGD di lokasi pertambakan PPNI yang hanya dihadiri oleh perempuan menumpahkan isi hati mereka.

$\begin{array}{ll}\text { JP (Jurnal Perempuan) } & \text { : Ibu-lbu, tadi dari FGD } \\ & \text { ibu-ibu bercerita bahwa } \\ & \text { hampir } 17 \text { jam per } \\ & \text { hari digunakan untuk } \\ & \text { pertambakan. Apakah ibu- } \\ & \text { ibu di sini merasa sebagai } \\ & \text { seorang petambak? }\end{array}$

Kerumunan : lya.

Waidah

Ida

$J P$

Kerumunan

Sumarsih

$J P$

Sumarsih

$J P$

Sumarsih lya, 100\%. Cuma itu kan pun tidak punya, karena kartu keanggotaan P3UW hanya dimiliki oleh bapak 
petambak. Untuk ibu petambak belum ada. Katanya sekarang lagi diusulin tapi belum tahu juga ya. Padahal kalau ada apa-apa ditanya mana kartu P3UW sebagai tanda kamu petambak? Ya gak ada. Karena kami sebagai perempuan emang ga ada (kartu). Anggota P3UW memang khusus BapakBapak.

$J P$

Sumarsih

Esra
: Itu aturan dalam struktur organisasi P3UW?

: lya memang aturannya seperti itu.

: Aku ini bekerja penuh di tambak. Dari aku mulai bangun pagi, mengurus makan dan menyiapkan anak pergi ke sekolah, aku anter, habis itu udah, aku sibuk di tambak itu. Mulai dari pengecekan, lalu simulasi, kira-kira nanti udang ini mulai makannya ditambah atau tidak, kemudian apakah butuh vitamin atau tidak. Aku terlibat.

Protes perempuan petambak Dipasena menarik. Sebab mereka merasa pekerjaan mereka tidak diakui. Apalagi P3UW adalah wadah masyarakat yang dibentuk awalnya sebagai upaya melawan kesewenangwenangan perusahaan dan melindungi hak-hak petambak udang yang mandiri. Namun, P3UW hingga hari ini tidak menerima petambak udang perempuan. Nafian Faiz berkilah bahwa di anggaran dasar P3UW belum mengakomodasi petambak perempuan. Menurutnya, semangat pendirian P3UW awalnya adalah semangat muda. "Belum ada yang jadi janda, petambak yang ditinggal suami. Karena belum diakomodasi dalam anggaran dasar, maka kami membuat organisasi informal yaitu Bareta P3UW, atau Bareta PPNI" (Faiz 2017, wawancara 26 Agustus). Di dalam kasus ini jelas apa yang diungkapkan Nussbaum menjadi penting. Pertama, kapabilitas perempuan petambak Dipasena tidak diakui (terutama kemartabatan dan aktualisasi diri mereka sebagai petambak udang), kedua, functioning perempuan petambak di lihat dari "hanya layak menjadi petambak bila tidak ada suami (janda)" atau cukup bila dibuatkan organisasi Bareta P3UW.

1. Dalam menegakkan keadilan dengan menggunakan kerangka kerja kapabilitas, Nussbaum berangkat dari pertanyaan "Apakah yang disebut kemartabatan manusia?" Jawaban yang singkat adalah bahwa pemerintah memiliki tanggung jawab dalam membuat masyarakatnya hidup dengan bermartabat dan kehidupan yang bertumbuh kembang. Untuk dapat memenuhi persyaratan tersebut Nussbaum memberikan 10 kategori.

2. Kehidupan. Mampu untuk hidup dalam jangka waktu yang wajar; tidak meninggal secara prematur, atau hidup seseorang diredusir menjadi tidak berarti.

3. Kesehatan tubuh. Mampu untuk memiliki kesehatan yang baik, termasuk kesehatan reproduksi; cukup pangan; memiliki tempat tinggal.

4. Integritas ketubuhan. Dapat pindah dari satu tempat ke tempat lainnya dengan bebas; jauh dari kekerasan, termasuk penyerangan seksual dan kekerasan domestik; memiliki kepuasan seksual dan pilihan dalam reproduksi.

5. Pancaindra, imajinasi dan pemikiran. Dapat menggunakan pancaindra, imajinasi berpikir, dan berakal sehat-dan dapat menggunakan semua itu secara "manusiawi", cara yang memiliki informasi dan pengetahuan yang cukup, termasuk dan tidak terbatas pada literasi dan latar belakang ilmu pengetahuan dan matematika. Dapat menggunakan imajinasi dan pemikiran dalam hubungannya dengan pengalaman dan produksi kerja dan pilihan sendiri, agama, kesusastraan, musik dan seterusnya. Dapat menggunakan pikiran sendiri yang dilindungi oleh kebebasan berekspresi dengan menghormati cara menyampaikan pendapat secara politis maupun artistik, dan kebebasan mempraktikkan agama. Memiliki pengalaman-pengalaman yang menyenangkan dan menghindari kesengsaraan dan rasa sakit.

6. Emosi. Dapat berafiliasi dan memiliki barang dan orang yang di luar diri sendiri; mencintai orang yang kita cintai dan sayang, berduka saat mereka pergi; secara umum dapat mencintai, berduka, mengalami kehilangan, rasa bersyukur, dan kemarahan yang beralasan. Tidak dihalangi rasa emosi karena ketakutan dan kecemasan. (Mendukung kapabilitas ini artinya mendukung semua bentuk asosiasi manusia yang dapat menjadi penting dalam pertumbuhan dan perkembangannya).

7. Kemampuan berpikir etis. Mampu merumuskan konsep kebaikan dan dapat berefleksi secara kritis dalam merencanakan hidup diri sendiri (Ini termasuk melindungi kebebasan berkesadaran dan praktik agama).

8. Afliasi. (A) Dapat hidup bersama dengan yang lain, mengakui dan peduli pada yang lain, dapat berpartisipasi dalam berbagai interaksi sosial; 
mampu berimajinasi dan memahami situasi orang lain. (Melindungi kapabilitas ini artinya melindungi institusi yang mendirikan dan merawat bentukbentuk afiliasi ini, dan juga melindungi kebebasan untuk berkumpul dan kebebasan berekspresi secara politis). (B) Memiliki basis sosial harga diri dan tidak dipermalukan; dapat diperlakukan sebagai manusia yang bermartabat yang nilainya sama dengan yang lainnya. Ini termasuk menyediakan fasilitas yang nondiskriminatif seperti diskriminasi ras, seks, orientasi seksual, etnisitas, kasta, agama, asal usul.

9. Makhluk hidup lainnya. Mampu hidup dengan makhluk hidup lainnya, peduli pada binatang, tumbuh-tumbuhan dan dunia lingkungan hidup.

10. Bermain. Dapat tertawa, bermain dan menikmati aktivitas-aktivitas rekreasi.

11. Mengendalikan lingkungan sendiri. (A) Politis. Mampu berpartisipasi secara efektif dalam pilihanpilihan politis yang sesuai dengan kehidupan diri sendiri; memiliki hak partisipasi politis, melindungi kebebasan berbicara dan asosiasi. (B) Material. Dapat memiliki properti (tanah maupun bendabenda yang bergerak), dan memiliki hak-hak kepemilikan setara dengan yang lain; memiliki hak untuk mencari pekerjaan dengan basis yang setara dengan yang lain; bebas dari razia dan perampasan. Di tempat kerja, diperlakukan secara manusiawi, dapat menggunakan rasio praktis dan memiliki hubungan kerja yang bermakna dan diakui oleh sesama pekerja.
Kapabilitas diperuntukkan bagi individu bukan untuk kelompok. Prinsip kapabilitas adalah setiap orang dilihat sebagai hasil akhir bukan alat yang digunakan untuk mencapai hasil akhir. Tujuannya adalah agar setiap orang dapat menggunakan kapabilitasnya secara penuh. Ini penting untuk pembuat kebijakan, karena banyak negara menganggap keluarga sebagai sesuatu yang homogen misalnya, dan tidak memeriksa dan mempromosikan kapabilitas yang berbeda dari setiap orang (Nussbaum 2011, h. 397). Berangkat dari kategori Nussbaum, kita dapat melihat persoalan yang dihadapi oleh petambak perempuan di Dipasena. Persoalan utama dari petambak perempuan Dipasena bukan persoalan pendapatan karena bagaimanapun pendapatan mereka di atas ratarata bila dihitung dari kategori nelayan perempuan lainnya (lihat penelitian di Demak dan Gresik dalam Jurnal Perempuan 95, 2017). ${ }^{8}$ Persoalan petambak perempuan Dipasena adalah persoalan kemartabatan diri yang tidak diakui memiliki profesi. Ini di dalam analisis Nussbaum menjadi persoalan yang urgen. Negara cenderung melihat persoalan dari segi material dan pertimbangan budaya serta agama (kacamata kelompok bukan individu), padahal persoalan petambak perempuan Dipasena adalah pengakuan dan eksistensi diri dan kemampuan untuk menentukan jalan hidup sendiri. Berikut analisis wacana petambak perempuan Dipasena menggunakan pisau analisis Nussbaum:

\section{Tabel 4: Analisis Pernyataan Petambak Perempuan dalam Kerangka Nussbaum}

\section{Pernyataan Petambak Perempuan:}

Aku bekerja dari mulai bangun pagi, mengurus makan anak dan suami, menyiapkan anak pergi ke sekolah, mengurus tambak 24 jam.

Saya petambak udang. Wong saya yang openi, saya yang urusin segala sesuatunya, dari persiapan benurnya, pakannya, panennya, ikut menentukan harga.

Mengapa kita tidak dianggap? Tidak diakui? Belum mendapat fasilitas-fasilitas seperti asuransi kerja, kesehatan?

Bapak disebut petambak, ibu disebut "ibu petambak", artinya ngikut bapak. Kenapa?

\section{Kategori Nussbaum yang tidak diakui:}

-Kemampuan berpikir etis: Mampu merumuskan konsep kebaikan dan dapat berefleksi secara kritis dalam merencanakan hidup diri sendiri.

-Afiliasi: Diperlakukan sebagai manusia yang bermartabat yang nilainya sama dengan yang lainnya

-Mengendalikan lingkungan sendiri: Mampu berpartisipasi secara efektif dalam pilihan-pilihan politis yang sesuai dengan kehidupan diri sendiri

-Afiliasi: Memiliki basis sosial harga diri dan tidak dipermalukan; diperlakukan sebagai manusia yang bermartabat yang nilainya sama dengan yang lainnya. Ini termasuk menyediakan fasilitas yang nondiskriminatif.

-Afiliasi: Memiliki basis sosial harga diri dan tidak dipermalukan; diperlakukan sebagai manusia yang bermartabat yang nilainya sama dengan yang lainnya.

-Pancaindra, imajinasi, pemikiran: Dapat menggunakan imajinasi dan pemikiran dalam hubungannya dengan pengalaman dan produksi kerja dan pilihan sendiri. 
Kepemilikan tambak atas nama suami.

Kami petambak bukan IRT (Ibu Rumah Tangga) mengapa kami tidak punya kartu anggota P3UW?

\section{Pernyataan Petambak Perempuan:}

\section{Kategori Nussbaum yang tidak diakui:}

-Mengendalikan lingkungan sendiri: Dapat memiliki properti (tanah maupun benda-benda yang bergerak), dan memiliki hak-hak kepemilikan setara dengan yang lain.

-Afiliasi: Memiliki basis sosial harga diri dan tidak dipermalukan; diperlakukan sebagai manusia yang bermartabat yang nilainya sama dengan yang lainnya.

-Mengendalikan lingkungan sendiri: dapat menggunakan rasio praktis dan memiliki hubungan kerja yang bermakna dan diakui oleh sesama pekerja.

Kami menuntut diberikan KTN (Kartu Tanda Nelayan), -Afiliasi: Memiliki basis sosial harga diri dan tidak keadilan gender harus ada. dipermalukan; diperlakukan sebagai manusia yang bermartabat yang nilainya sama dengan yang lainnya.

\section{Saya ingin punya kartu identitas disebut petambak} udang.

Kita sebenarnya sama. Yang membedakan perempuan dan laki-laki hanya bentuknya saja. Laki-laki punya jakun, penis dan perempuan punya payudara dan rahim, hanya beda jenis kelaminnya saja tapi selebihnya sama. Mengapa kerja kami tidak diakui?

Kami ingin perempuan diajak diskusi, bisa mengambil keputusan. Ini perkumpulan bersama tapi perempuan tidak bisa jadi pemimpin.

-Afiliasi: Memiliki basis sosial harga diri dan tidak dipermalukan; diperlakukan sebagai manusia yang bermartabat yang nilainya sama dengan yang lainnya.

Emosi: Tidak dihalangi rasa emosi karena ketakutan dan kecemasan (mendukung kapabilitas ini artinya mendukung semua bentuk asosiasi manusia yang dapat menjadi penting dalam pertumbuhan dan perkembangannya).

-Afiliasi: Memiliki basis sosial harga diri dan tidak dipermalukan; diperlakukan sebagai manusia yang bermartabat yang nilainya sama dengan yang lainnya.

-Mengendalikan lingkungan sendiri: dapat menggunakan rasio praktis dan memiliki hubungan kerja yang bermakna dan diakui oleh sesama pekerja.

Kami senang berorganisasi, PPNI beda dengan PKK. Di PPNI kami belajar gender, tahu hak-hak kami.

Fasilitas kesehatan minim, tidak ada Rumah Sakit. Jalan kami rusak berat membutuhkan 8 jam untuk ke kota. Tidak ada rumah sakit bersalin, dokter ahli.
-Emosi: Tidak dihalangi rasa emosi karena ketakutan dan kecemasan (mendukung kapabilitas ini artinya mendukung semua bentuk asosiasi manusia yang dapat menjadi penting dalam pertumbuhan dan perkembangannya).

-Bermain. Dapat tertawa, bermain dan menikmati aktivitas-aktivitas rekreasi.

- Kesehatan tubuh: Mampu untuk memiliki kesehatan yang baik, termasuk kesehatan reproduksi.

Sumber: diolah dari data lapangan, Agustus 2017

\section{Penutup}

Pembangunan dalam definisi Sen dan Nussbaum bukan berarti fisik dan instrumental untuk pembangunan bangsa. Fokus dari argumentasi Sen dan Nussbaum adalah pembangunan manusia. Khususnya pada Nussbaum, ia menyoroti beban kerja perempuan yang dihitung baik di ranah publik maupun privat. Petambak perempuan Dipasena menunjukkan beban berat yang dipikul dan aktivitas kerja secara keseluruhan yang lebih dari 17 jam sehari, sebab mayoritas perempuan juga mengamankan tambak mereka di malam hari.

Bagi Nussbaum melihat permasalahan pembangunan adalah melihat permasalahan kehidupan manusia dan bagaimana manusia dapat berkembang dan berkontribusi secara maksimal dan bermartabat dalam kehidupannya. Maka Nussbaum menekankan unsur penghormatan pada eksistensi manusia. Dalam hal kasus perempuan petambak Dipasena, jelas mereka sangat 
mempersoalkan pengakuan mereka sebagai petambak udang. Seluruh eksistensi mereka sebagai pekerja tidak didukung oleh pengakuan (hitam di atas putih) bahwa mereka adalah anggota sah wadah sebuah profesi misalnya P3UW atau lebih jauh lagi diakui secara nasional dengan adanya Kartu Nelayan. Pengakuan tersebut berimplikasi praktis, yakni, mereka bisa mendapatkan dukungan untuk mengembangkan usaha tambak mereka, mendapatkan asuransi kerja, pelatihan, dan sebagainya. Tetapi lebih dari itu, pengakuan mereka sebagai pekerja profesional di bidang budi daya udang seharusnya memanusiakan mereka, memerhatikan kapabilitas mereka.

Pemerintah seringkali bertumpu pada analisis kerangka berpikir ekonomi cost benefit, padahal kerangka berpikir demikian tidak akan mampu memahami pembangunan berdasarkan kemanusiaan. Nussbaum menegaskan bahwa pembangunan seharusnya berangkat dari analisis keadilan. Dengan demikian, pembangunan yang manusiawi, artinya pembangunan yang mempertimbangkan eksistensi perempuan seutuhnya.

\section{Daftar Pustaka}

Artharini, I 2016, "Perempuan Nelayan di Indonesia Menunggu Diakui", BBC Indonesia.com, 13 Januari, diakses 23 September 2016. http://www.bbc.com/indonesia/majalah/2016/01/160113_ majalah_nelayan_perempuan_

Fadilasari, D 2012, Kemitraan, Konflik, dan Perlawanan Petani Udang, Sijado Institute, Lampung.

Sen, A 1999, Development as Freedom, Anchor Books, New York, E-book.

Nussbaum, MC 1999, Woman and Cultural Universals, Oxford University Press, Oxford.
Nussbaum, M 2011, Creating Capabilities, The Human Development Approach, Harvard University Press, Massachusetts.

\section{Catatan Akhir:}

1 Pakan udang: pemberian makan udang memerlukan teknik khusus. Pakan menghabiskan anggaran tertinggi dalam budi daya udang, maka mengontrol dan mengatur pemberikan pakan harus sangat teliti. Bila memberikan pakan berlebihan bisa merusak udang.

2 Cek Ancho: Alat untuk mengontrol pemberian pakan udang. Cara penggunaannya adalah setiap kali memberi pakan pada jam pakan tertentu perlu ditaburi pakan sedikit pada jaring ancho sesuai dengan berat udang. Jika pakan dalam ancho habis maka ditambah bila tidak maka dikurangi sehingga harus terus-menerus dikontrol.

3 Siphon: teknik pengeluaran kotoran/sampah organik dari kotoran udang, udang mati, plankton mati dan makhluk hidup lainnya yang bisa menjadi racun. Mengeluarkan kotoran yang menjadi lumpur dilakukan dengan menyedot lewat selang di bawah dasar tambak.

4 Minapolitan adalah konsep pembangunan kelautan dan perikanan berbasis wilayah melalui pendekatan sistem manajemen kawasan dengan prinsip integrasi, efisiensi, kualitas, dan akselerasi.

5 Buku Fadilasari (2007) menggambarkan bagaimana rekrutmen petambak PT Dipasena yang kriterianya adalah laki-laki dan dilatih dengan cara militer, kekuatan fisik.

6 Sen mengambil konsep flourishing dari Etika Nichomachean Aristoteles.

7 Ibu Sumarsih adalah seorang janda petambak, sejak tahun 2012 ia mengelola tambak udang seorang diri.

8 Pendapatan petambak dari hasil produksi pola tradisional berkisar Rp 12 juta-Rp 15 juta, pola semiintensif berkisar Rp 25 juta-Rp 50 juta dan pola intensif lebih dari Rp 50 juta per siklus (tenor masa produksi 3 bulan). 


\section{Ucapan Terima Kasih pada Mitra Bestari}
1. Dr. Pinky Saptandari (Universitas Airlangga)
2. Dr. Kristi Poerwandari (Universitas Indonesia)
3. Dr. Ida Ruwaida Noor (Universitas Indonesia)
4. Ro'fah Makin, Ph.D. (UIN Sunan Kalijaga)
5. Antarini Pratiwi Arna (Oxfam in Indonesia)
6. Dr. Wening Udasmoro (Universitas Gadjah Mada) 

